\title{
Building Ability of Sport Students Statistical Reasoning through Statistical Reasoning Learning Environment (SRLE)
}

\author{
Nidaul Hidayah* \\ Departemen Pendidikan Kepelatihan Olahraga \\ Universitas Pendidikan Indonesia \\ Bandung, Indonesia \\ *nidaul@upi.edu
}

\author{
Wahyudin Wahyudin, Turmudi Turmudi \\ Departemen Pendidikan Matematika \\ Universitas Pendidikan Indonesia \\ Bandung, Indonesia
}

\begin{abstract}
This study discusses learning models that can improve statistical reasoning skills for sports students who take statistics courses. Statistical Reasoning Learning Environment or abbreviated as SRLE is a learning model based on constructivist social theory with six learning principles which focus on developing statistical content, using real data, using classroom activities, using technology assistance, improving classroom conversation and using alternative assessments. The purpose of this study is that through SRLE learning models can improve the statistical reasoning abilities of sports students. The research method used is quasi-experimental method. The sample used was 58 students of the SCE study program (Sports Coaching Education) which was divided into two groups, namely the experimental group and the control group, each of which was 29 students. The results obtained that students who attend statistical lectures with SRLE models have higher achievement and increased statistical reasoning skills than students who take direct (conventional) learning. SRLE as alternative statistical learning for students sport.
\end{abstract}

Keywords-SRLE; statistical reasoning; students sport

\section{INTRODUCTION}

The role of statistics in sports is so great because in various competitions and competitions there will be achievements that are expressed with speed (in sports and swimming), with the frequency (number of scores entered) for example in basketball, soccer, badminton, volleyball and so forth so that the results of the competition and the race produce data that can be processed and presented statistically. Research on sports statistics has been widely carried out, Albert and Ruud in his book "Statistical Thinking in Sport" provides information on survey results that are accessed from current research in statistics and sports [1]. Among these studies are "Modeling The Development Of World Records in Running" research Kuper and Sterken from the University of Groningen illustrate a development of a world record model of a race running from 100 meters to marathon numbers for men and women by method times-series [2]. Other research is "Statistical Analysis of the Effectiveness of the FIFA World Rankings" which was examined Mchale and Davies from the University of Salford
[3]. This study builds a forecasting model for the results of football matches between national teams, and assesses the extent to which the information includes having been given the right weight in FIFA rankings.

Furthermore, Tabor in the book "Statistical Reasoning in Sport" provides an overview of how statistical learning is delivered with sports as its context [4]. In the learning process using real data for sports investigations which are discussed in various media either through the internet or directly from the field.

Building on the importance of statistics in sports both for research, education and evaluation for training or competition, literacy (literacy) and statistical reasoning skills for sports students are necessary. Statistical reasoning is defined as a way of reasoning by involving statistical ideas and information [5]. For example: making interpretations based on data, data representations, or summary statistics from data. Statistical reasoning can be a combination of ideas and probabilities, such as concluding and interpreting statistical results. Statistical reasoning means understanding concepts and being able to explain statistical processes, and is able to fully interpret statistical results [6]. Later, Lovett interprets statistical reasoning as: "using statistical tools and statistical concepts to summarize, make predictions about data, and draw conclusions from data" [7]. Similar statements are proposed by Dani and Joan that statistical reasoning is a way of thinking using facts of statistical information [8]. Thus statistical reasoning can be defined as a way of reasoning by involving statistical ideas and information to summarize, make predictions about data and draw conclusions from the data. The ability of statistical reasoning is the ability to understand statistical concepts, explain statistical processes and interpret statistical results based on statistical ideas and information.

Traditional statistical learning only focuses on the calculation, skills and knowledge of grouping / classifying data [9]. In sports student activities, there are many things that can be used as statistical learning material both in matches, test results and measurements, for example predicting achievements that can be achieved based on the training 
process, and seeing the relationship between one variable and other variables and others. Based on the results of a preliminary study, it is shown that studying statistics for sports students is only used as a tool to calculate and process data not to understand the concept, practice statistical literacy and statistical reasoning skills. From these results it can also be concluded that innovative learning is needed so that statistics courses can be well understood, both procedurally and in their meanings and concepts.

The learning model that will be used in this research is a learning model to develop statistical reasoning abilities introduced by Garfield and Ben-Zvi [10], namely "Statistical Reasoning Learning Environment" or abbreviated SRLE. SRLE is a learning model based on constructivist social theory with six learning principles designed by Cobb and McClain which focuses on developing statistical content, using real data, using classroom activities, using technology assistance, improving classroom conversation and using alternative assessments [9]. This SRLE learning model is a studentcentered learning model. Through the SRLE learning model, it is expected to have a positive impact on the quality of statistical learning outcomes for sports students so that it can improve statistical reasoning skills that are very useful for athletes both as athletes, teachers, trainers or sports people.

The reform of the learning of statistics among them was examined by Loveland that an activity-based learning approach provides an understanding of statistical concepts and the ability to apply statistical procedures better [11]. Activity-based learning also gives students a more positive attitude towards statistics. In addition what Kamariah has examined gives results that engineering students at UTHM (Universit Tun Husein Onn Malaysia) who study statistics through laboratory activities with contextual learning gain higher cognitive outcomes than non-contextual learning and statistical laboratory activities help understanding concepts and motivation in statistical learning [12]. Ulpah in his dissertation which implies that contextual learning can be applied to students of Madrasah Aliyah to improve statistical reasoning skills and self-efficacy of students [13]. Takaria concluded that there was an increase in statistical literacy skills, mathematical and self-concept representation of prospective elementary school teachers taught through the Collaborative Problem Solving model [14]. Lanani shows that the achievement of statistical reasoning ability of students who obtain ICT-assisted project-based learning is higher than students who obtain conventional learning, both at each class level and overall [15]. Nurashiken provide the results of research that statistical learning through SRLE with video (instructional video statistical reasoning (VPPS)) increases students' statistical understanding and receives video as a tool and reference in learning so that learning can be done without time and place limitation [16]. Chan showed the results of the study that the SRLE teaching had a major impact on improving students' statistical reasoning ability based on the Rash analysis method [17].

From the preliminary study and the results of the above studies, the author encouraged the research to be applied to students of sports study programs, to find out the impact of the
Statistical Reasoning Learning Environment (SRLE) learning model to build statistical reasoning skills

\section{Method OF RESEARCH}

The method used in this study is the 'quasi-experiment' method which aims to find out how far SRLE learning can improve the statistical reasoning abilities of sports students. The design in this study is' The Group pretest-posttest design.

The experimental group was given a learning treatment by applying Statistical Reasoning Learning Environment (SRLE) while the control group was treated with Direct Learning (DL).

The object of research is statistical reasoning ability and SRLE and direct learning models. While the subjects in this study were FPOK Sports Coaching Education Study Program students from the Indonesian Education University who took statistics courses. The data collection instrument used is a test of statistical reasoning ability in the form of questions relating to inferential statistics namely hypothesis testing, t-test, correlation and regression that have fulfilled validity and reliability.

This research activity was carried out in three stages, namely the pre-test with the aim to determine the students' statistical reasoning abilities before being given treatment, then the sample was divided into two groups where one experimental group and one control group. Next is the provision of treatment in the form of learning with SRLE learning models (experiments) and Direct Learning models (DL) for the control group, and the third stage is post-test with the aim of knowing the students' statistical reasoning abilities after being given treatment. The research was carried out in short semester lectures (SP) with a sample of 58 students, namely 29 students in the experimental group and 29 students in the control group. In this study the statistical material provided was inferential statistical material which was carried out in 10 meetings.

\section{RESULTS AND DISCUSSION}

The ability of statistical reasoning is obtained from the results of pretest, posttest and increase ( $\mathrm{N}$-gain). Results of analysis of statistical reasoning ability Students from the SRLE learning group (experimental group) and direct learning group (control group) are descriptively presented in table 1 below:

TABLE I. DESCRIPTION OF DATA ON STATISTIC REASONING ABILITY RSA STUDENTS OF BOTH LEARNING GROUPS

\begin{tabular}{|l|l|l|l|l|l|l|}
\hline \multirow{2}{*}{ Statistic } & \multicolumn{5}{|c|}{ Learning } \\
\cline { 2 - 7 } & \multicolumn{5}{|c|}{ PRLE } & \multicolumn{2}{c|}{ Direct (conventional) } \\
\hline & Pretes & Postes & N-gain & Pretes & Postes & N-gain \\
\hline N & 29 & 29 & 29 & 29 & 29 & 29 \\
\hline Mean & 7,41 & 79,14 & 0,5063 & 7,76 & 42,41 & 0,2464 \\
\hline Std Dev & 8,196 & 25,251 & 0,1637 & 9,022 & 31,385 & 0,2073 \\
\hline
\end{tabular}

The pretest data on statistical reasoning ability of the two learning groups needs to be tested whether there is a difference or not to aim to further strengthen the impact of the SRLE learning model applied. The results of the processing of the test 
pretest, posttest and N-gain of the two sample groups between the experimental group (SRLE learning model) and the control group (direct learning model) are as follows:

- Because the results of the SRA score normality test are not normally normal, then the average two difference test is done by Mann Whitney-U test. Respectively are the distribution of pretest scores, achievement (posttest), and increase ( $\mathrm{N}$-gain) of SRA from the population of students who have learned SRLE and DL

- By using SPSS software related to $\mathrm{t}$ test and Mann Whitney-U test, the following outputs are obtained for the pretest data obtained the probability value of sig is 0.916 , this value is greater than alpha 0.05 so that the null hypothesis is accepted, meaning that there is no difference in the mean pretest data of the two learning groups. From the results of this analysis, the authors concluded that the two learning groups were eligible to be given different treatment. If there is a difference at the end of the learning, the difference can be seen as a result of different treatment.

- To test the hypothesis the posttest data (achievement) of PPP is obtained by the probability value of sig. $=0,000$ $<0.05=\alpha$ then the null hypothesis ( $\mathrm{H} 0)$ is rejected. This shows that there is an average difference in the achievement of statistical reasoning abilities in the SRLE learning group with the average achievement of statistical reasoning abilities in groups of students who use direct learning (control group). It can also be noted that the average achievement of statistical reasoning ability in the SRLE learning group of students obtained post-test average SRLE $=79.14$ is higher than the average achievement of statistical reasoning ability groups that use direct learning (control group) where the average the posttest was 42.41. Thus, the average achievement of students' statistical reasoning ability through SRLE learning was higher than the statistical reasoning ability of student groups that used direct learning (control group).

- Furthermore, to test the data N-gain (increase) is obtained by the probability value of sig. $=0.00<0.05=$ $\alpha$ then the null hypothesis (H0) is rejected. This shows that there is a difference in the average increase in statistical reasoning ability of the group of SRLE learning students with an average increase in statistical reasoning ability of groups using direct learning (control group). It can also pay attention to the average increase in statistical reasoning ability in the group of students learning SRLE (average N-gain $=0.5063$ ) higher than the average increase in statistical reasoning ability groups that use direct learning (control group) on average $\mathrm{N}$ - gain $=0.2464$. Thus, the average increase in students' statistical reasoning ability through SRLE learning is higher than the average increase in statistical reasoning ability of groups of students who use direct learning (control group). SRLE learning is more productive and able to foster the strengthening of concepts to students because the SRLE learning model adheres to the flow of social constructivism, where one is required to find his own knowledge. Through the philosophical foundation of constructivism, students are expected to learn through "experiencing" rather than "memorizing". Then through the use of technology will improve the process of interpreting a statistical concept because it will reduce the time of calculations that are procedural in nature [6].

\section{CONCLUSION}

From the results of research that has been done based on the results of statistical data processing it can be concluded that:

- There is a difference in the average achievement of statistical reasoning ability in the group of SRLE learning students with an average achievement of statistical reasoning abilities in groups of students who use direct learning (control group). There is a difference in the average increase in statistical reasoning ability in the group of SRLE learning students with an average increase in statistical reasoning abilities of groups that use direct learning (control group). The Statistical Reasoning Learning Environment has an impact on the improvement and achievement of statistical reasoning abilities of SCE Study Program students who follow statistics courses. The average increase and achievement of statistical reasoning ability in the student group of SRLE learning is higher than the average increase and the achievement of statistical reasoning abilities in groups that use direct learning (control group).

\section{ACKNOWLEDGMENT}

Thanks to Universitas Pendidikan Indonesia, special thanks to Fakultas Pendidikan Olahraga dan Kesehatan (FPOK)

\section{REFERENCES}

[1] J. Albert and K. Ruud, Statistical Thinking in Sport. Chapman \& Hall CRC Taylor \& Francis Group, 2008.

[2] Kuper and Sterken, Modelling the Development of World Records in Running. Library of Congress in Publication Data, 2007.

[3] Mchale and Davies, Statistical Analysis of Effectiveness of the FIFA World Rankings. Library of Congress in Publication Data, 2007

[4] Tabor, Statistical Reasoning in Sports. New York: W.H. Freeman and Company, 2013.

[5] R. DelMas, J. Garfield, and B. Chance, "A model of classroom research in action: Developing simulation activities to improve students' statistical reasoning," Journal of Statistics Education, vol. 7(3), 1999.

[6] J.B. Garfield, "The Challenge of Developing Statistical Reasoning," Journal of Statistics Education, vol. 10(3), 2002.

[7] M. Lovett, "A Collaborative Convergence on Studying Reasoning Processes: A case study in statistics," In S. M. Carver \& D. Klahr (Eds.), cognition and instruction: Twenty-five years of progress, pp. 347-384, 2001 .

[8] B.Z. Dani and G. Joan, "Statistical literacy, reasoning, and thinking: Goals, definitions, and challenges," In The challenge of developing statistical literacy, reasoning and thinking, pp. 3-15, 2004. 
[9] J. Garfield, B. Hogg, C. Schau, and D. Whittinghill, "First courses in statistical science: The status of educational reform efforts," Journal of statistics education, vol. 10(2), 2002.

[10] J. Garfield, and D. Ben-Zvi, "Helping students develop statistical reasoning: Implementing a statistical reasoning learning environment" Teaching Statistics, vol. 31(3), pp. 72-77, 2009.

[11] J.L. Loveland, Traditional lecture versus an activity approach for teaching statistics: A comparison of outcomes, 2014.

[12] Kamariah, "A Study of the Effectiveness of the Contextual Lab Activity in the Teaching and Learning Statistics at the UTHM," in US-China Education Review, vol. A.1, pp. 13-19, 2012.

[13] M. Ulpah, Peningkatan Kemampuan Penalaran Statistis Dan SelfEfficacy Siswa Madrasah Aliyah Melalui Pembelajaran Kontekstual. Dissertation, Universitas Pendidikan Indonesia, 2013
[14] J. Takaria, Peningkeatan Literasi Statistis, Representasi Matematis, dan Self Concept Mahasiswa Calon Guru Sekolah Dasar Melalui Mode Collaborative Problem Solving. Dissertation, Universitas Pendidikan Indonesia, 2015

[15] K. Lanani, Kemampuan penalaran Statistis, Komunikasi Statistis dan Academic Help-Seeking Mahasiswa dalam Pembelajaran Berbasis Proyek Berbantuan ICT, Disertasi, Uiversitas Pendidikan Indonesia, 2015

[16] N. Ismail, "Statisitical Reasoning Learning Environment (SRLE) in Teaching Video Improved Statistical Reasoning Skills," Proceeding International Seminar on Innovation in Mathematics and Mathematics Education ISIM-MED, 2014.

[17] S. Wei Chan, Z. Ismail, and B. Sumintono, "The Impact of Statistica Reasoning Learning Environment: A Rasch Analysis," Advanced Science Letters, vol. 21(5), pp. 1211-1215, 2015. 